\title{
STEM INJECTION OF INSECTICIDES TO CONTROL HERBIVOROUS INSECTS ON EUCALYPTUS NITENS
}

\author{
S.F. GOUS and B. RICHARDSON \\ Forest Biosecurity and Protection, Scion, Private Bag 3020, Rotorua,
New Zealand
}

Corresponding author: stefan.gous@scionresearch.com

\begin{abstract}
To minimise environmental impact in urban and recreational environments, insecticides may be injected directly into the vascular system of trees rather than by conventional foliar spray application. In previous stem injection trials, the majority of injected insecticides did not provide effective control of herbivorous insects. This was largely because of the insolubility of the formulated insecticide products available in New Zealand. Three water soluble insecticides, acephate, imidacloprid and emamectin benzoate, were injected directly into the xylem of Eucalyptus nitens. In subsequent laboratory bioassays the effect of these insecticides were assessed on two leaf feeding insects, Uraba lugens (gum leaf skeletoniser) and Trachymela sloanei (a eucalyptus tortoise beetle). The results indicate that acephate may be a suitable candidate for protecting trees using stem injection of insecticides but in this study imidacloprid and emamectin benzoate were not effective.

Keywords: stem injection, Uraba lugens, Trachymela sloanei, acephate, imidacloprid, emamectin benzoate.
\end{abstract}

\section{INTRODUCTION}

Conventional foliar spray application methods are often not considered appropriate or publicly acceptable in urban and recreational environments. By applying insecticides directly into the vascular system of trees, the environmental impact of insecticides is reduced compared with conventional techniques. Suitable stem injected systemic insecticides are rapidly absorbed by the host plant and translocated throughout its tissues making foliage toxic to herbivorous insect pests. The use of systemic insecticides in stem injection systems to control herbivorous and sap sucking insects is well documented (e.g. Helson et al. 2001; Massimo 2001; Wanner et al. 2002; Kreutzweiser et al. 2007). However, in previous New Zealand studies (Gous 2005) the majority of insecticides tested did not provide effective control of herbivorous insects largely because of the insolubility of the products available in New Zealand. When applied as conventional foliar sprays, solubility and systemic properties of insecticides may not be critical to ensure good insect control (Gous 2005; Mansfield et al. 2006). However, mortality of herbivorous insects is largely influenced by these properties when the insecticides are injected into the stem of the host plant (Scott \& Gous 2005; Gous 2005). Stem injections directly apply insecticides into the vascular system of a tree, which eliminates drift and limits environmental exposure. Stem injected systemic insecticides are absorbed by the host plants within hours, and are translocated throughout the tissues, making the host's foliage toxic to herbivorous insect pests.

Stem injection for insect control is impractical in large plantations due to the high numbers of trees and the associated labour costs. However, it is appropriate for high value individual trees or small stands of trees in parks, gardens or roadside plantings. It is useful especially where trees are too tall for spraying from the ground, and/or where environmental constraints do not allow the spraying of insecticides. This experiment 
was conducted to determine whether stem injected water soluble insecticides would successfully translocate into host tree foliage to control foliar-feeding pests.

\section{Insecticides}

\section{MATERIALS AND METHODS}

Three water soluble insecticides, acephate, imidacloprid and emamectin benzoate, that had not previously been used for stem injection in New Zealand, were injected into Eucalyptus nitens to evaluate their efficacy against Uraba lugens (Lepidoptera: Noctuidae) and Trachymela sloanei (Coleoptera: Chrysomelidae), two insects that feed on Eucalyptus nitens and some common Myrtaceae trees in New Zealand (Table 1). Orthene and Proclaim are registered for use in New Zealand but are not currently recommended for stem injection. Merit $200 \mathrm{SL}$ is a soluble liquid formulation of imidacloprid produced by Bayer Australia.

TABLE 1: Insecticides used for stem injection against $U$. lugens and $T$. sloanei.

\begin{tabular}{llcc}
\hline & $\begin{array}{l}\text { Active ingredient (ai) } \\
\text { concentration }\end{array}$ & $\begin{array}{c}\text { Rate injected } \\
\text { (g ai/ cm tree } \\
\text { diameter) }\end{array}$ & Chemical group \\
\hline Oroduct name & acephate $-970 \mathrm{~g} / \mathrm{kg}$ & 0.25 & Organo-phosphate \\
Merit 200 SL & imidacloprid $-200 \mathrm{~g} /$ litre & 0.20 & Chloronicotinyl \\
Proclaim & emamectin benzoate $-50 \mathrm{~g} / \mathrm{kg}$ & 0.20 & Avermectin \\
\hline
\end{tabular}

\section{Location and layout}

The trial was conducted at Kapenga tree farm ( $\left.38^{\circ} 14^{\prime} 15.07^{\prime \prime} \mathrm{S} ; 176^{\circ} 13^{\prime} 17.53^{\prime \prime} \mathrm{E}\right)$ approximately $15 \mathrm{~km}$ south west of Rotorua. Seven-year-old Eucalyptus nitens trees with an average diameter of $21.8 \mathrm{~cm}$ were injected with one of the three insecticides (Table 1). For acephate and imidacloprid, ten trees each were injected. The emamectin benzoate treatment had only $5 \mathrm{~g} / \mathrm{kg}$ ai, and therefore required high volumes of solution to be injected to reach the desired dose. This combined with high liquid viscosity (saturated solution) made it difficult to achieve and after five unsuccessful attempts further attempts were abandoned. The five partially-treated trees remained in the bioassay trials.

\section{Insecticide rates}

Each tree was injected twice, using a Sidewinder Precision Injector (Sidewinder Pty Ltd) into opposite sides of the trunk at $130 \mathrm{~cm}$ above ground. Insecticide rates were based on tree diameter and the quantity of active ingredient recommended by the manufacturer. Acephate was injected at $0.25 \mathrm{~g}$ ai $(=1.8 \mathrm{ml}) / \mathrm{cm}$ tree diameter, imidacloprid was injected as neat product at $0.2 \mathrm{~g}$ ai $(=1 \mathrm{ml}) / \mathrm{cm}$ tree diameter and emamectin benzoate was injected at $0.2 \mathrm{~g}$ ai $(=8 \mathrm{ml}) / \mathrm{cm}$ tree diameter.

\section{Bioassays}

Mature foliage was randomly sampled from the injected trees and untreated control trees between 14 and 150 days after treatment (Table 2). All foliage was taken at $7 \mathrm{~m}$ above ground level. Samples were placed in plastic bags, labelled and kept under refrigeration at $4^{\circ} \mathrm{C}$ until used in the bioassays.

Stems bearing leaves were individually placed in water and the upper portion of each stem confined within a $395 \mathrm{ml}$ test chamber (Matsuki et al.2001). Five mature T. sloanei beetles and/or five 9th instar U. lugens larvae from laboratory colonies were placed in each test arena. Insect mortality was assessed after 3 and 7 days.

The results were analysed by Analysis of Variance and Tukey's Honestly Significantly Different (HSD) multiple comparison tests. Tukey's (HSD) test was used because it is very conservative in revealing significant differences between treatment means.

\section{RESULTS AND DISCUSSION}

Due to a disease in the $U$. lugens colony, caterpillars were not always available for bioassays. When available, bioassays were conducted with both $U$.lugens and T. sloanei, 
otherwise only $T$. sloane $i$ was used. There were significant differences between insecticide treatments, with acephate causing mortality of T. sloanei (Table 2) up to 49 days post treatment and of $U$. lugens (Table 3 ) up to 150 days after insecticide injection. Neither imidacloprid nor emamectin benzoate were associated with greater mortality of $T$. sloane $i$ than measured for untreated trees in any bioassay and on only one occasion (emamectin benzoate after 70 days) was survival of $U$. lugens affected by either of these treatments. The results for both insects indicate that acephate translocated rapidly (within 14 days) into the foliage and caused significant mortality to T. sloanei and $U$. lugens.

TABLE 2: Trachymela sloanei mortality (\%) after 7 days exposure in bioassays to $E$. nitens foliage from trees that had been injected with insecticides 14 to 150 days previously.

\begin{tabular}{lrrrrrrrrrrr}
\hline & \multicolumn{10}{c}{ Days after injection } \\
\cline { 2 - 12 } Treatment & \multicolumn{1}{c}{14} & 21 & 28 & 35 & 42 & 49 & 56 & 63 & 70 & 119 & 150 \\
\hline Control & $0 \mathrm{~b}^{1}$ & $0 \mathrm{~b}$ & $0 \mathrm{~b}$ & $4 \mathrm{a}$ & $4 \mathrm{~b}$ & $0 \mathrm{~b}$ & $0 \mathrm{a}$ & $0 \mathrm{a}$ & $0 \mathrm{a}$ & $0 \mathrm{a}$ & $8 \mathrm{a}$ \\
acephate & $56 \mathrm{a}$ & $42 \mathrm{a}$ & $70 \mathrm{a}$ & $46 \mathrm{a}$ & $46 \mathrm{a}$ & $56 \mathrm{a}$ & $34 \mathrm{a}$ & $20 \mathrm{a}$ & $22 \mathrm{a}$ & $6 \mathrm{a}$ & $8 \mathrm{a}$ \\
imidacloprid & $4 \mathrm{~b}$ & $4 \mathrm{~b}$ & $18 \mathrm{~b}$ & $6 \mathrm{a}$ & $6 \mathrm{~b}$ & $8 \mathrm{~b}$ & $12 \mathrm{a}$ & $6 \mathrm{a}$ & $6 \mathrm{a}$ & $4 \mathrm{a}$ & $4 \mathrm{a}$ \\
emamectin & $0 \mathrm{~b}$ & $2 \mathrm{~b}$ & $0 \mathrm{~b}$ & $24 \mathrm{a}$ & $4 \mathrm{~b}$ & $0 \mathrm{~b}$ & $4 \mathrm{a}$ & $8 \mathrm{a}$ & $8 \mathrm{a}$ & $0 \mathrm{a}$ & $0 \mathrm{a}$ \\
\hline
\end{tabular}

${ }^{1}$ Values in a column followed by the same letter do not differ significantly $(\mathrm{P}=0.05)$ Tukey (HSD).

TABLE 3: Uraba lugens mortality (\%) after 7 days exposure in bioassays to $E$. nitens foliage from trees that had been injected with insecticides 14 to 150 days previously.

\begin{tabular}{llrrrrr}
\hline & \multicolumn{7}{c}{ Days after injection } \\
\cline { 2 - 7 } Treatment & 14 & 56 & 63 & 70 & 119 & 150 \\
\hline Control & $20 \mathrm{~b}^{1}$ & $4 \mathrm{~b}$ & $16 \mathrm{~b}$ & $4 \mathrm{c}$ & $0 \mathrm{~b}$ & $4 \mathrm{~b}$ \\
acephate & $76 \mathrm{a}$ & $56 \mathrm{a}$ & $80 \mathrm{a}$ & $60 \mathrm{a}$ & $56 \mathrm{a}$ & $36 \mathrm{a}$ \\
imidacloprid & $20 \mathrm{~b}$ & $4 \mathrm{~b}$ & $18 \mathrm{~b}$ & $16 \mathrm{bc}$ & $0 \mathrm{~b}$ & $0 \mathrm{~b}$ \\
emamectin & $45 \mathrm{~b}$ & $0 \mathrm{~b}$ & $12 \mathrm{~b}$ & $40 \mathrm{ab}$ & $0 \mathrm{~b}$ & $0 \mathrm{~b}$ \\
\hline
\end{tabular}

${ }^{1}$ Values in a column followed by the same letter do not differ significantly $(\mathrm{P}=0.05)$ Tukey (HSD).

Uraba lugens appeared more sensitive to injected acephate than T. sloanei based on bioassay mortalities.

The results from trees injected with imidacloprid and emamectin benzoate suggest that these insecticides are either not effective against $T$. sloanei and $U$. lugens at the rates used or that they were not translocated within the tree at sufficient concentrations to cause mortality.

Emamectin benzoate is registered for use against Lepidoptera. As a stem injection treatment it produced a $71 \%$ reduction of Asian longhorned beetles (Anoplophora glabripennis) on Salix spp. and reduced coneworm (Dioryctria spp.) damage by $94-97 \%$ on Pinus taeda (Poland et al. 2006; Grosman et al. 2002). Emamectin benzoate is isolated from fermentation of Streptomyces avermitilis. It has translaminar properties but is not known to be systemic (New Zealand Novachem Agrichemical Manual 2007; Tomlin 2006). These facts, coupled with the difficulties experienced (high viscosity and high volume) during tree injection, make the low efficacy of this treatment unsurprising. 
Imidacloprid was used successfully in stem injections against Asian longhorned beetle (Anoplophora glabripennis) on Picea spp., Ulmus spp., Populus spp. and Salix spp. (Kreutzweiser et al. 2007; Poland et al. 2006). It has also been used with success against brown spruce longhorned beetle (Tetropium fuscum) on Picea spp., Emerald ash borer (Agrilus planipennis) on Fraxinus spp., leaffooted pine seed bug (Leptoglossus corculus) and shieldbacked pine seed bug (Tetyra bipunttata) on Pinus taeda (Kreutzweiser et al. 2007; Grosman et al. 2002). Imidacloprid is a systemic, chloro-neonicotinyl insecticide that is readily taken up by both foliage and root-systemic action (Kreutzweiser et al.2007; Tomlin 2006). However, it still performed poorly against the two tested insects when used for trunk injections in Eucalyptus nitens. Imidacloprid is registered for use against sucking and soil insects (Tomlin 2006). According to the manufacturers, imidacloprid is not particularly effective against Lepidoptera (P. Lallu, Bayer NZ, 2007, pers. comm.). It is suspected that this is largely due to herbivorous insects not ingesting large quantities of the tree sap, which contains the insecticide, compared to sap sucking insects, which ingest large quantities of low nutrient sap, thereby ingesting much larger doses of the insecticide. Injection of much larger doses should be investigated to establish if this theory is correct.

Of the injected insecticides, acephate has the lowest acute oral LD50 (lethal dose to kill $50 \%$ of test population) of $1447 \mathrm{mg} / \mathrm{kg}$ in rats compared to $76 \mathrm{mg} / \mathrm{kg}$ and $450 \mathrm{mg} / \mathrm{kg}$ for emamectin benzoate and imidacloprid respectively (Tomlin 2006). Acephate's acute dermal LD50 was greater than $2000 \mathrm{mg} / \mathrm{kg}$, which makes this product reasonably safe to handle and an ideal treatment for stem injections where environmental exposure is largely eliminated. Acephate is systemic, easy to inject, simple to mix and the least expensive and most efficacious of the insecticides used in this trial. For these reasons acephate shows the greatest promise to use in stem injections.

All insecticides should be handled and applied by operators in possession of appropriate qualifications as required by the HSNO regulations of 2001. The Sidewinder Injector is both a drill and injector in one, which allows one person to inject trees. It is a relatively easy to use device, but requires some training and experience to ensure safe and secure injections.

\section{CONCLUSIONS}

Acephate was an easy-to-use, and effective option for stem injection treatments and results from this study shows promise for use in stem injection systems. Imidacloprid was also easy to use in stem injections, but at the injected rates did not provide effective control to either of the target insects in this study. Emamectin benzoate was nearly impossible to inject and provided very little control of the target insects. In the current available formulation it is not a viable option for stem injections.

\section{ACKNOWLEDGEMENTS}

This project was funded by Biosecurity New Zealand. Thanks to Lindsay Bulman for comments and management assistance; Belinda Gresham, Caro Gous, Pam Taylor and Dave Hayes for bio-assays and foliage collections; and Barry Poole and Steve Kinchef, Hardwood Management New Zealand, for permission to inject trees at Kapenga tree farm.

\section{REFERENCES}

Gous SF 2005. Stem Injection - Dose response trials and bioassays. Confidential Scion Report 11515 for FBRC and MAF. Scion, Rotorua, New Zealand.

Grosman DM, Upton WW, McCook FA, Billings RF 2002. Systemic insecticide injections for control of cone seed insects in Loblolly pine seed orchards -2 year results. Southern Journal of Applied Forestry 26(3): 146-152.

Helson BV, Lyons DB, Wanner KW, Scarr TA 2001. Control of conifer defoliators with neem-based systemic insecticides using a novel injection device. The Canadian Entomoligist 133: 729-744. 
Kreutzweiser DK, Good K, Chartrand D, Scarr T, Thompson D 2007. Non-target effects on aquatic decomposer organisms of imidacloprid as a systemic insecticide to control emerald ash borer in riparian trees. Ecotoxicology and Environmental Safety 68: 315-325.

Mansfield S, Withers TM, Gous SF, Potter KJB, Kriticos DJ, Watson M, Kimberley MO 2006. Potential of selective insecticides for managing Uraba lugens (Lepidoptera: Nolidae) on eucalypts. Journal of Economic Entomology 99(3): 780-789.

Massimo F 2001. Elm bark beetles and Dutch Elm Disease: tests of combined control. Anzeiger fur Schädlingskunde 74 (1): 22-29.

Matsuki M, Kay M, Serin J, Floyd R, Scott JK 2001. Potential risk of accidental introduction of Asian gypsy moth (Lymantria dispar) to Australasia: effects of climatic conditions and suitability of native plants. Agricultural and Forest Entomology 3: 305-320.

Novachem Manual 2006/2007 A New Zealand guide to agrichemicals for plant protection. Novachem Services Ltd, Palmerston North, New Zealand. 471 pp.

Poland TM, Haack RA, Petrice TR, Miller DL, Bauer LS, Gao R 2006. Field evaluations of systemic insecticides for control of Anoplophora glabripennis (Coleoptera: Cerambycida) in China. Journal of Economic Entomology 99(2): 383-392.

Scott G, Gous SF 2005. The chemical analysis of pesticides in stem injection trials. Confidential Scion Report 11358 for FBRC and MAF. Scion, Rotorua, New Zealand.

Tomlin CDS ed. 2006. The pesticide manual: a world compendium, 14th edition. British Crop Protection Enterprises, Hampshire, UK. 1344 pp.

Wanner KW, Helson BV, Harris BJ 2002. Laboratory evaluation of two novel strategies to control first-instar gypsy moth larvae with spinosad applied to tree trunks. Pest Management Science 58: 817-824. 